\title{
An Analysis of the US Mutual Funds Sector: What Determines Performance?
}

\section{Faisal Mahmood* and Ghulame Rubbaniy}

\begin{abstract}
This paper analyzes the performance of equity mutual funds in the US, using monthly data for a sample of 4,431 equity mutual funds over the period 1999-2012. Our empirical findings suggest that larger funds with higher liquidity and turnover generate higher returns, while expenses and management fees have a negative impact on performance.
\end{abstract}

Keywords: Equity mutual funds, liquidity, fund size.

JEL classification: G11, G23.

\section{Introduction}

Mutual funds refer to money pooled together by several investors and managed by sophisticated fund managers who use their skills to obtain high returns. Mutual funds give individual investors an opportunity to invest in a professionally managed diversified portfolio and have recently gained popularity in global markets. The total net asset holdings of global mutual funds increased from US\$ 11.9 trillion in 2000 to US\$23.80 trillion in 2011 (Investment Company Institute, 2012). Jiang, Luo and Tian (2012) show that the number of mutual funds rose substantially from 55,523 to 69,519 over the period 2004 to 2010 .

The US mutual funds market is the world's biggest fund market, accounting for 49 percent of the global mutual funds industry, with a net asset value of US\$ 11.6 trillion in 2011. This has led investors around the world to invest in various types of US mutual funds, including domestic funds, world equity funds, bonds and money market funds. Apart from deciding which category to invest in, investors need to assess the size and growth of the mutual funds market. Fund performance is a key determinant of such decisions, making it important to examine not only performance trends, but also the factors affecting fund performance.

\footnotetext{
* PhD scholar, Lahore Business School, University of Lahore.
} 
This study evaluates the determinants of mutual fund performance in the US by looking at equity mutual funds, which account for 33 percent of the country's mutual funds sector (Investment Company Institute, 2012). The sheer volume of investment and the number of stakeholders involved makes this an important exercise. ${ }^{1}$ The literature looks at three broad aspects of this subject. The first part deals with the relationship between fund managers' abilities and fund performance. The second part examines persistent performance in fund returns. The third part analyzes which factors drive fund performance, including expense ratios, management fees, fund wealth, fund style, risk, cash flows, management structure and fund age.

Factors such as fund liquidity, however, need further investigation ${ }^{2}$ and the literature provides no conclusive evidence of its impact on mutual fund performance. Accordingly, we look at the effect of fund liquidity, fund turnover, fund size, management fees and expense ratios on equity mutual funds in the US. Our findings suggest that liquidity, size and turnover have a positive, significant impact on fund performance. The rest of the paper is structured as follows. Section 2 provides a review of the literature. Sections 3 and 4 describe the dataset and methodology used. Section 5 gives our empirical results and Section 6 concludes the study.

\section{Literature Review}

Investment in mutual funds has increased rapidly in the last two decades, giving even small investors the advantages of professional fund management and portfolio diversification. An important aspect of portfolio management is estimating the fund's performance. ${ }^{3}$ Given that mutual funds are seen to yield high returns in the public eye and that numerous factors affect their performance, this can be difficult to do. The literature in this area looks at the relative importance of these factors and how they drive investment decisions.

Sharpe (1966) studies 34 open-ended mutual funds over the period 1954-63 and shows how expense ratios and past performance explain the diversity in performance of mutual funds. Jensen (1968) examines 115

\footnotetext{
${ }^{1}$ Other studies in this area include Wermers (2000); Daniel, Grinblatt, Titman and Wermers (1997); Jensen (1968); Fu (2009); and Ang, Hodrick, Xing and Zhang (2006).

${ }^{2}$ The consensus in the literature is that higher levels of risk are associated with higher returns and that fund styles (passive, active, market timing and stock picking abilities) affect performance.

${ }^{3}$ Past performance does not, however, guarantee the same results: many other factors affect the performance of a mutual fund.
} 
mutual funds for the period 1945-64 and underscores the importance of estimating security prices. He argues that mutual funds must estimate their research benefits, cost and trading activity to ensure higher returns at acceptable levels of risk.

Malkiel (1995) identifies patterns in mutual fund returns that present an investment opportunity and allow investors to earn riskadjusted excess returns. ${ }^{4}$ Mutual funds tend to underperform the market after meeting their management expenses and reported expenditures (except for fund loads). Thus, management fees and fund expenses have a negative impact on mutual fund performance. Ciccotello and Grant (1996) study 626 equity mutual funds over the period 1982-92 and find that the largest funds are associated with better past performance. This implies that aggressive investors can use fund size to forecast future performance.

In a study on US mutual funds, Gruber (1996) points to customer service, low transaction costs, diversification and professional management as central reasons for holding mutual funds. He also finds that better management is associated with persistence in fund performance, while the best-performing funds have lower expenses. This makes fund performance predictable to some extent. Carhart (1997) analyzes persistent performance among mutual funds during $1962-93$ by considering investment expenditure and stock returns. The results indicate a significant, negative relationship between performance and portfolio turnover and expense ratios. A key finding is that fund performance is negatively affected by transaction costs, load fees and expense ratios.

Indro, Jiang, Hu and Lee (1999) study the effect of fund size on the performance of equity funds in the US over the period 1993-95. They argue that such funds should be small enough to earn sufficient returns to meet the purchase cost involved. Wermers (2000) measures mutual fund performance for the period 1975-94 by decomposing returns and expenses/costs into different components. The results show that the stock returns on mutual funds outperform the market index. Generally, mutual funds underperform due to fund expenses and management fees. Funds with a higher turnover tend to perform better.

Otten and Bams (2002) show that the risk-adjusted performance of mutual funds in Europe is driven by fund size, age and management expenses. The results suggest that small cap funds are capable of value

\footnotetext{
${ }^{4}$ The opportunity to earn larger risk-adjusted returns.
} 
addition. ${ }^{5}$ The funds in question have positive after-cost alphas, explaining their optimism. ${ }^{6}$ Small cap mutual funds perform better than their benchmarks because they have lower management fees than larger funds. Compared to US mutual funds, European mutual funds provide additional benefits such as diversification, lower transaction costs and positive returns.

Using panel data for 600 US mutual funds over the period 19952001, Latzko (2002) finds that the operating cost of a mutual fund is central to understanding the sector. He argues that average-sized funds tend to enjoy economies of scale, while their larger counterparts face diseconomies of scale. Ruckman (2003) studies trends in the expense ratio of mutual funds in North America and finds that Canadian investors pay a 50 percent higher expense ratio than US investors. This may be a result of lower competition and economies of scale. The study also shows that Canadian investors are more likely to buy rear-end load funds than frontend load funds, whereas the choice of funds is equally weighted among US investors.

Looking at US equity funds for the period 1962-99, Chen, Hong, Huang and Kubik (2004) find that the relationship between fund size and liquidity wears down the performance of these funds. Goel, Sharma and Mani (2012) analyze 160 open-ended mutual funds over the period 2006-11 and identify a lead-lag relationship for fund performance. They show that the expense ratio is negatively correlated with performance, while the size of the fund is positively related to its performance.

Jiang et al. (2012) investigate the relationship between fund promotion and performance in the Chinese mutual funds sector during 2004-10. They find little evidence that promoting a fund helps predict its future performance. Investors with poor fund selection ability are more likely to be attracted by fund promotion, which implies that mutual funds with a superior capital inflow will not necessarily perform better in the future. Tang, Wang and $\mathrm{Xu}$ (2012) analyze the relationship between size and performance in the Chinese mutual funds sector over the period 200409. They find that size has a positive impact on performance, but this effect is constrained by the fund's liquidity.

\footnotetext{
5 Although the definition varies among brokers, funds with market capitalization of US\$ 300 million to US\$ 2 billion are considered small cap funds.

${ }^{6}$ The alpha coefficient measures risk-adjusted performance. The after-cost alpha measures the fund's performance after it has met its costs.
} 
Dong, Feng and Sadka (2012) show that higher liquidity can result in greater future returns. The investment skills of a fund manager are related to liquidity exposure and the performance of mutual funds. In addition to liquidity risk, investors should account for other factors such as performance persistence, smart money and size when forecasting mutual fund performance. ${ }^{7}$ Vidal-Garcia and Vidal (2013) investigate the effect of liquidity and idiosyncratic risk on the European market for mutual funds and find that performance is influenced by liquidity and idiosyncratic risk. They also show that both variables can be tested jointly without affecting the other's influence.

Narayan and Zheng (2011) examine the impact of liquidity on mutual fund performance in China over the period 1997-2003. They find a negative relationship between liquidity and mutual fund returns on the Shenzhen and Shanghai stock exchanges. Wagner and Winter (2013) explore the impact of idiosyncratic risk and liquidity on the performance of mutual funds in Europe for the period 2002-09. They show that both liquidity and idiosyncratic risk determine performance, where liquidity has a positive impact on mutual fund performance. Even when measured together, neither variable reduces the magnitude of the other's effect.

Overall, the literature yields mixed findings on the relationship between mutual fund characteristics and performance: liquidity in particular can have a positive or negative impact on the former (Dong et al., 2012; Narayan \& Zheng, 2011; Tang et al., 2012). Accordingly, we aim to reinvestigate the relationship between liquidity and mutual fund performance in the US.

\section{Data and Variables}

The data used is drawn from Thomson Reuters (for CUSIPs) ${ }^{8}$ and the Center for Research in Security Prices (CRSP) (for mutual fund returns and characteristics). The sample comprises 4,431 US equity mutual funds over the period 1999-2012. Table 1 defines each variable. The data for fund turnover ratio, management fee and expenses has already been calculated in the CRSP database; we calculate the remaining data ourselves.

\footnotetext{
${ }^{7}$ Money investment by well-informed investors.

8 The CUSIP number identifies a North American security, including all registered US and Canadian stocks as well as US government and municipal bonds.
} 
Table 1: Definition of variables

\begin{tabular}{ll}
\hline Variable & \multicolumn{1}{c}{ Definition } \\
\hline Dependent variable & Mutual fund returns \\
Fund performance & \\
Explanatory variables & Ratio of fund returns to turnover \\
Liquidity & Total net asset value of portfolio \\
Fund size & Turnover ratio of fund \\
Fund turnover & \\
Control variables & Expense ratio of fund \\
Fund expenses & Management fee ratio of fund \\
Management fee & \\
\hline
\end{tabular}

While the management fee (charged by the fund manager) differs from fund to fund, it often depends on the value of assets being managed and can be 0.5 percent of the underlying asset. ${ }^{9}$ Fund expenses refer to the cost of operating a mutual fund and are measured by its expense ratio. These expenses include taxes, legal expenses, accounting charges, marketing fees and auditing fees. Fund loads and redemption fees are also costs, but are not included in the expense ratio.

Table 2 reports the descriptive statistics for the sample. The values indicate that all the variables have a normal mean, median and standard deviation except fund size, the value of which is measured in millions and varies widely across funds. Size is measured by the total net asset value of the fund. The average total net asset value is US\$2,495.32 million, with a median value of 396.15 and a standard deviation of 7,223.30, indicating that the data is highly dispersed. Fund returns measure the monthly return on the mutual fund. The mean value shows that, on average, the sample funds generate 0.004 percent in returns, with a median value of 0.01 percent and a standard deviation of 0.05 .

\footnotetext{
${ }^{9} \mathrm{http}: / / \mathrm{www}$.investopedia.com/terms/m/managementfee.asp
} 
Table 2: Summary statistics

\begin{tabular}{lccc}
\hline Variable & Mean & Median & SD \\
\hline Fund returns & 0.00401 & 0.01 & 0.05114 \\
Liquidity & 0.01698 & 0.01 & 1.78090 \\
Fund turnover & 0.03376 & 0.53 & 9.4201 \\
Fund size (in US\$ million) & $2,495.32$ & 396.15 & $7,223.30$ \\
Fund expenses & 0.06880 & 0.01 & 2.7172 \\
Management fee ratio & 0.37090 & 0.58 & 14.776 \\
\hline
\end{tabular}

Note: The expense ratio (the ratio of total investment to fund operating expenses) is usually lower than the management fee ratio due to reimbursements and waivers. The fund turnover is the ratio of the lowest aggregate purchase or sale of securities to total net assets (12-month average).

Source: Authors' calculations based on data from the CRSP.

\section{Methodology}

This section describes the study's hypotheses and empirical model.

\subsection{Research Hypotheses}

The literature does not provide a consensus on the relationship between liquidity and fund returns. Some studies find that this relationship is positive, while others suggest it is negative (see Wagner \& Winter, 2013; Vidal-Garcia \& Vidal, 2013; Narayan \& Zheng, 2011). We propose that liquidity has a positive impact on mutual fund performance.

Similarly, the findings on the impact of turnover on performance are inconsistent, with some studies pointing to a positive relationship and others to a negative relationship (see Carhart, 1997; Wermers, 2000). When turnover is associated with transaction costs, this yields decreasing fund returns. However, when adjusted for market variations, it is associated with higher returns. We expect to find a positive relationship between fund turnover and performance.

Again, other studies have established a positive as well as negative relationship between fund size and performance (see Indro et al., 1999; Goel et al., 2012). Some studies find no relationship at all (see Johansson \& Jacobsson, 2012). We propose that there is a positive relationship between fund size and performance. 


\subsection{Empirical Model}

We employ the following multiple linear regression (MLR) model:

$$
M F R_{i t}=\beta_{0}+\beta_{1} L_{i q}+\beta_{2} \text { Turn }_{i t}+\beta_{3} \text { Size }_{i t}+\beta_{4} F e e_{i t}+\beta_{5} \operatorname{Exp}_{i t}+\varepsilon_{i t}
$$

Here, $\beta_{0}$ is the y-intercept and $M F R_{i t}$ is the return on mutual fund $i$ at time $t$. $\beta_{1}$ to $\beta_{5}$ represent fund liquidity, turnover, size, management fees and expenses, respectively. $\varepsilon_{i t}$ is the error term, which is an independent, identically distributed random variable for fund $i$ at time $t$.

Our empirical analysis uses panel data procedures. Although using panel data has several benefits, its drawbacks need to be addressed by using either a fixed effects (FE) or random effects (RE) model. ${ }^{10}$ This choice is determined as follows. When the time variable $\mathrm{T}$ is high and the crosssection units variable $\mathrm{N}$ is low, there will be very little difference between the parameters whether we use FE or RE. However, if $\mathrm{N}$ is larger than $\mathrm{T}$, both models will yield variations between the parameters (see Gujarati, 2003). Under the Hausman (1978) test, the null hypothesis is that there is no difference between FE and RE estimators. Based on the data, if the null hypothesis is rejected, we can use either FE or RE. If the value of the Hausman test statistic is $>x^{2}<0.05$, then an FE model is used. If its value is $>x^{2}>0.05$, an RE model is used.

\section{Empirical Results}

Table 3 shows the correlation among all the explanatory variables. Since there is no exact or strong correlation among the variables, the data is deemed free from multicollinearity problems. The results of the MLR model given in Equation (1) are presented in Table 4.

\footnotetext{
${ }^{10}$ The FE model allows the intercept to vary between entities and is used in case of correlation between the intercept and explanatory variables. In the RE model, the intercept is random and has a constant, stable mean. This is used if the intercept and explanatory variables are uncorrelated.
} 
Table 3: Correlation among explanatory variables

\begin{tabular}{lrcccc}
\hline Variable & Size & Liquidity & Expenses & Turnover & $\begin{array}{c}\text { Management } \\
\text { fee }\end{array}$ \\
\hline Size & 1.000 & & & & \\
Liquidity & 0.001 & 1.0000 & & & \\
Fund expenses & -0.008 & -0.0010 & 1.000 & & \\
Fund turnover & -0.019 & 0.0006 & 0.006 & 1.000 & \\
Management fee & 0.001 & -0.0046 & 0.008 & 0.001 & 1.000 \\
\hline
\end{tabular}

Source: Authors' calculations based on data from the CRSP.

The results show that fund size, liquidity and turnover have a statistically significant impact on mutual fund performance. Liquidity has a positive, economically significant impact on fund performance and is highly significant at the 1 percent level. A 1 percent increase in liquidity increases performance by 0.28 percent, ceteris paribus. This result supports our hypothesis that liquidity has a positive impact on fund performance.

Table 4: Impact of explanatory variables on dependent variable (MLR)

\begin{tabular}{lcc}
\hline Variable & Coefficient & Prob. \\
\hline Constant & $0.00370^{*}$ & 0.00 \\
& $(0.00010)$ & \\
Liquidity & $0.00280^{*}$ & 0.00 \\
& $(0.00010)$ & \\
Fund turnover & $.01640^{*}$ & 0.00 \\
& $(0.00545)$ & \\
Fund size & $0.00660^{*}$ & 0.00 \\
& $(0.00220)$ & 0.87 \\
Fund expenses & -0.00840 & \\
& $(0.05390)$ & 0.11 \\
Management fee & $-0.00180^{* *}$ & \\
& $(0.00117)$ & \\
\hline
\end{tabular}

Note: Fund returns $=0.0037+0.0028$ (liquidity) +0.016 (turnover $)+0.0066($ size $)-0.0084$ (expenses) -0.0018 (management fee) $+u$.

${ }^{*}=$ significant at $1 \%$ level, ${ }^{* *}=$ significant at $5 \%$ level, ${ }^{* * *}=$ significant at $10 \%$ level. Thus, depending on the p-value, three variables are statistically significant.

Source: Authors' calculations based on data from the CRSP.

Fund turnover has an economically and statistically significant, positive impact on mutual fund performance at the 1 percent level. Ceteris paribus, a 1 percent increase in turnover increases fund performance by 
1.64 percent. This supports our hypothesis as well as the argument that funds adjusted for market variations generate higher returns than those associated with a transaction cost. Fund size has a positive impact on performance and is highly significant at the 1 percent level. The latter rises by 0.0066 units following a one-unit increase in fund size, implying that larger funds yield higher returns. This result supports our hypothesis that fund size is positively correlated with performance.

The expense ratio has an economically significant, but statistically insignificant negative impact on fund performance. Thus, mutual funds with higher expenses do not perform as well. The management fee has a statistically and economically significant, negative impact on performance at the 5 percent level. With a one-unit decrease in the management fee, fund performance falls by 0.0018 units. A lower management fee, therefore, is associated with higher returns.

The Hausman test results show that the probability statistic (prob. > $x^{2}=0.000$ ) is significant, indicating that we should use an FE model (Table 5). Individual-specific effects are considered fixed in this case: assuming that they may influence the independent variables, the FE model removes time-invariant characteristics from the explanatory variables to assess the net effect of the predictors used. The RE model considers time-invariant individual factors to be random variables that are uncorrelated with the independent variables. This allows the results to be generalized across the population, whereas FE model results are restricted to the sample.

Table 5: Hausman test results: comparison of RE and FE models

\begin{tabular}{lccrc}
\hline Variable & FE & RE & Difference & SE \\
\hline Liquidity & 0.002598 & 0.002737 & -0.000138 & 0.000023 \\
Fund turnover & 0.000033 & 0.000013 & 0.000020 & 0.001340 \\
Fund size & 0.001460 & 0.000090 & 0.001370 & 0.000123 \\
Fund expenses & -0.005570 & 0.000118 & -0.005450 & 0.000080 \\
Management fee & -0.000038 & 0.000014 & -0.000024 & 0.000029 \\
\hline
\end{tabular}

Note: Since the probability of $x^{2}$ is significant, we use an FE model: $x^{2}(5)=171.66$ prob. > $x^{2}=0.000$.

Source: Authors' calculations based on data from the CRSP.

Table 6 gives the results of the FE model and shows that liquidity, size and turnover have a statistically and economically significant impact on mutual fund performance, while fund expenses and management fees 
have an economically significant, but statistically insignificant impact on performance. Liquidity has a positive impact on the dependent variable and is highly significant at the 1 percent level. Ceteris paribus, a 1 percent rise in liquidity increases fund performance by 0.25 percent. In contrast to the MLR model, the FE model yields a small decrease (0.0002 units) in the economic significance of liquidity. The results imply that investors should focus on mutual funds with higher liquidity to obtain greater returns.

Table 6: Impact of explanatory variables on dependent variable (FE)

\begin{tabular}{lcc}
\hline & Coefficient & Prob. \\
\hline Constant & 0.0006 & 0.17 \\
& $(0.0004)$ & \\
Liquidity & $0.0026^{*}$ & 0.00 \\
& $(0.0001)$ & \\
Fund turnover & $0.0034^{* *}$ & 0.02 \\
& $(0.002)$ & \\
Fund size & $0.0015^{*}$ & 0.00 \\
& $(0.0001)$ & \\
Fund expense & -0.0055 & 0.60 \\
& $(0.010)$ & 0.24 \\
Management fees & -0.0038 & \\
& $(0.0033)$ & \\
\hline
\end{tabular}

Note: Fund returns $=0.0006+0.0026$ (liquidity) +0.0034 (turnover $)+0.0015$ (size) -0.0055 (expenses) -0.0038 (management fee) $+u$.

$*$ = significant at $1 \%$ level, ${ }^{* *}=$ significant at $5 \%$ level, ${ }^{* * *}=$ significant at $10 \%$ level. Thus, depending on the p-value, three variables are statistically significant.

Source: Authors' calculations based on data from the CRSP.

Fund turnover has a positive, statistically significant impact on performance at the 5 percent level. A 1 percent rise in turnover results in a 0.33 percent increase in fund performance, ceteris paribus. The turnover coefficient falls to 0.013 in the FE model. Thus, its economic significance decreases, but the variable remains statistically significant. The result suggests that funds adjusted for sectoral variations generate higher returns, implying that investors should favor those with a higher turnover.

Fund size has a highly significant, positive impact on mutual fund performance at the 1 percent level. With a one-unit rise in fund size, performance increases by 0.0015 units, ceteris paribus. In the FE case, the size coefficient decreases by 0.005 units. This relationship between fund size and performance suggests that larger funds yield higher returns. 
Fund expenses remain statistically insignificant in the FE model, but the economic impact increases by 0.0029 units. The variable has a negative impact on fund performance: an increase of one unit in fund expenses leads performance to fall by 0.0055 units, ceteris paribus. The management fee variable becomes statistically insignificant in the FE model. Ceteris paribus, a one-unit increase in the management fee causes fund performance to fall by 0.0038 units. The variable's economic significance decreases by 0.0020 units in the FE model. Overall, the results suggest that investors should favor larger equity mutual funds with higher liquidity and turnover in the US, rather than considering factors such as advertisement and other fund promotion techniques.

\section{Conclusion}

This empirical study investigates the determinants of performance for a sample of US equity mutual funds over the period 1999-2012. We find that fund size, liquidity and turnover help explain fund performance. Each of these variables has an economically and statistically significant impact on performance in the MLR and FE models.

Fund liquidity has a statistically as well as economically significant, positive impact on fund performance at the 1 percent level in both models. With a 1 percent increase in liquidity, mutual fund performance increases by 0.28 percent. This implies that funds with higher liquidity generate greater returns. This relationship is consistent with Wagner and Winter (2013) and Dong et al. (2012) and indicates that both investors as well as policymakers have reason to favor mutual funds with higher liquidity.

Fund turnover has a statistically and economically significant, positive impact on mutual fund performance in both the MLR and FE models at the 1 and 5 percent level, respectively. Performance increases by 0.0164 units following a one-unit increase in turnover. Thus, mutual funds with a higher turnover produce higher returns, making them more attractive to investors as well as policymakers. This result is consistent with Wermers (2000) and Dahlquist, Engström and Söderlind (2000).

Fund size has an economically and statistically significant, positive impact on mutual fund performance at the 1 percent level. A one-unit increase in fund size raises performance by 0.0066 units. This indicates that larger funds perform better. This relationship is consistent with Tang et al. (2012) and Goel et al. (2012), but contradicts Otten and Bams (2002) and Johansson and Jacobsson (2012). 
Fund expenses have an economically significant, but statistically insignificant, negative impact on fund performance. The management fee has an economically and statistically significant, negative impact on fund performance at the 5 percent level. This implies that fund expenses and management fees decrease returns. Thus, investors are more likely to select funds with lower expenses and management fees to obtain higher returns. This is consistent with Wermers (2000), Otten and Bams (2002) and Losen (2007).

This study could be extended by decomposing the dataset into subsamples, for instance, comparing fund performance during crisis and noncrisis periods. A comparative country study across the mutual funds sector in China and Europe could also be carried out, incorporating country-specific variables such as the strength of legal laws, investor protection, financial development and management structure.

A key limitation of the study is that it considers only three performance-related characteristics. Given the limited data available, we have not looked at factors such as the impact of idiosyncratic risk on mutual fund performance. Moreover, we have restricted the analysis to one country (the US), for which data was available. Finally, data limitations also mean that we have not accounted for categories such as growthfocused versus value-focused funds, aggressive versus nonaggressive funds or active versus passive funds. 


\section{References}

Ang, A., Hodrick, R. J., Xing, Y., \& Zhang, X. (2006). The cross-section of volatility and expected returns. The Journal of Finance, 61(1), 259299.

Carhart, M. M. (1997). On persistence in mutual fund performance. The Journal of Finance, 52(1), 57-82.

Chen, J., Hong, H., Huang, M., \& Kubik, J. D. (2004). Does fund size erode mutual fund performance? The role of liquidity and organization. American Economic Review, 94(5), 1276-1302.

Ciccotello, C. S., \& Grant, C. T. (1996). Equity fund size and growth: Implications for performance and selection. Financial Services Review, 5(1), 1-12.

Dahlquist, M., Engström, S., \& Söderlind, P. (2000). Performance and characteristics of Swedish mutual funds. Journal of Financial and Quantitative Analysis, 35(3), 409-423.

Daniel, K., Grinblatt, M., Titman, S., \& Wermers, R. (1997). Measuring mutual fund performance with characteristic-based benchmarks. The Journal of Finance, 52(3), 1035-1058.

Dong, X., Feng, S., \& Sadka, R. (2012, January). Liquidity risk and mutualfund returns. Paper presented at the Annual Meeting of the American Economic Association, Chicago, IL.

$\mathrm{Fu}, \mathrm{F}$. (2009). Idiosyncratic risk and the cross-section of expected stock returns. Journal of Financial Economics, 91(1), 24-37.

Goel, S., Sharma, R., \& Mani, M. (2012). A study of performance and characteristics of open-ended mutual funds. Asian Journal of Management Research, 3(1), 116-124.

Gruber, M. J. (1996). Another puzzle: The growth in actively managed mutual funds. The Journal of Finance, 51(3), 783-810.

Gujarati, D. N. (2003). Basic econometrics (4th ed.). New York: McGrawHill. 
Hausman, J. A. (1978). Specification tests in econometrics. Econometrica, $46(6), 1251-1271$.

Indro, D. C., Jiang, C. X., Hu, M. Y., \& Lee, W. Y. (1999). Mutual fund performance: Does fund size matter? Financial Analysts Journal, 55(3), 74-87.

Investment Company Institute. (2012). 2012 Investment Company fact book. Washington, DC: Author.

Jensen, M. C. (1968). The performance of mutual funds in the period 1945-1964. The Journal of Finance, 23(2), 389-416.

Jiang, P., Luo, X., \& Tian, S. (2012, July). Is mutual fund promotion bittersweet? Evidence from Chinese mutual funds. Paper presented at the China International Conference in Finance, Chongqing, China.

Johansson, T., \& Jacobsson, M. (2012). Size and performance of Swedish mutual funds: Does size matter? Unpublished Master's thesis, Jönköping International Business School, Sweden.

Latzko, D. A. (2002). Mutual fund expenses: An econometric investigation. Unpublished manuscript, Pennsylvania State University, State College, PA.

Losen, J. L. (2007). Mutual fund performance in Europe: A study of bank versus nonbank mutual funds. Unpublished Master's thesis, Maastricht University, Maastricht, the Netherlands.

Malkiel, B. G. (1995). Returns from investing in equity mutual funds 1971 to 1991. The Journal of Finance, 50(2), 549-572.

Narayan, P. K., \& Zheng, X. (2011). The relationship between liquidity and returns on the Chinese stock market. Journal of Asian Economics, 22(3), 259-266.

Otten, R., \& Bams, D. (2002). European mutual fund performance. European Financial Management, 8(1), 75-101.

Ruckman, K. (2003). Expense ratios of North American mutual funds. Canadian Journal of Economics, 36(1), 192-223. 
Sharpe, W. F. (1966). Mutual fund performance. The Journal of Business, 39(1), 119-138.

Tang, K., Wang, W., \& Xu, R. (2012). Size and performance of Chinese mutual funds: The role of economy of scale and liquidity. PacificBasin Finance Journal, 20(2), 228-246.

Vidal-Garcia, J., \& Vidal, M. (2013, September). Do liquidity and idiosyncratic risk matter? Evidence from the European mutual fund market. Paper presented at the AIDEA Bicentenary Conference, Lecce, Italy.

Wagner, N., \& Winter, E. (2013). A new family of equity style indices and mutual fund performance: Do liquidity and idiosyncratic risk matter? Journal of Empirical Finance, 21, 69-85.

Wermers, R. (2000). Mutual fund performance: An empirical decomposition into stock-picking talent, style, transactions costs and expenses. The Journal of Finance, 55(4), 1655-1703. 